ppi $201502 Z U 4645$

Esta publicación cientifica en formato digital es continuidad de la revista impresa ISSN-Versión Impresa 0798-1406 / ISSN-Versión on line 2542-3185Depósito legal pp

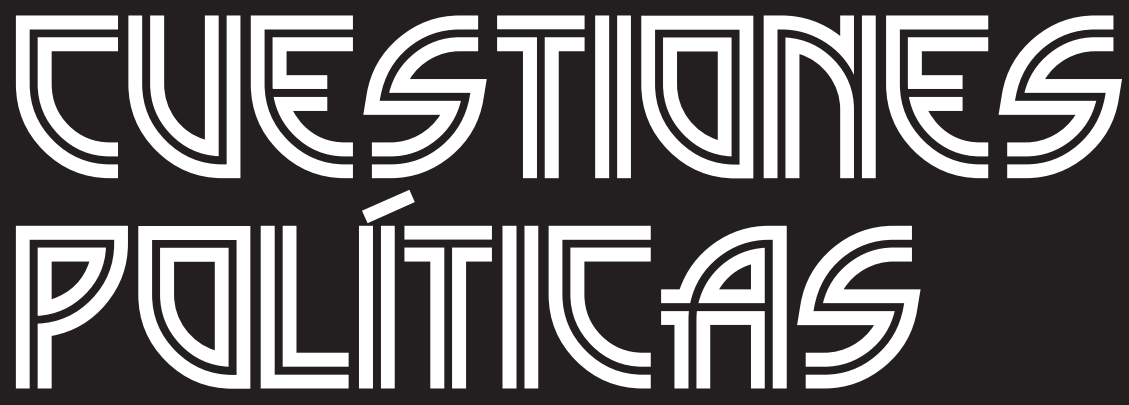

Instituto de Estudios Políticos y Derecho Público "Dr. Humberto J. La Roche' de la Facultad de Ciencias Jurídicas y Políticas de la Universidad del Zulia Maracaibo, Venezuela
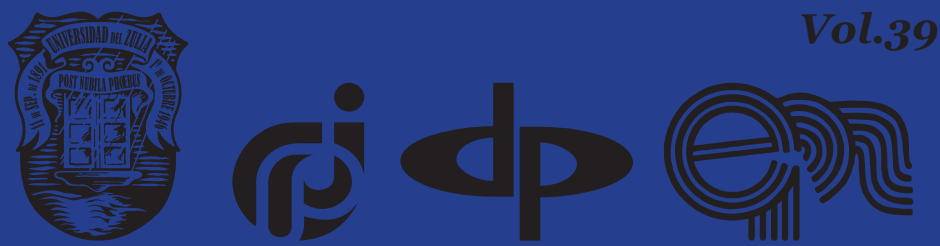


\title{
Public and Private Interests in the Sphere of Administration of Vaccination in a Pandemic
}

\author{
DOI: https://doi.org/10.46398/cuestpol.3968.30
}

\author{
Iryna Drobush * \\ Liudmila Kornuta ** \\ Olha Shmyndruk *** \\ Olena Kurhanska **** \\ Tetiana Polishchuk $* * * * *$
}

\begin{abstract}
COVID-19 has posed challenges to the global community at large and to jurisprudence in particular. In the current context, it is of paramount importance to find the best possible solutions in the field of legal regulation that help minimize the harmful effects of the global multisectoral crisis, save lives and restore the well-being of society. The work aims to clarify the theoretical problems in the legal status of medical innovations in the context of the COVID-19 pandemic. The subject of research is anticoronavirus innovations in the medical field. The research methods used were the dialectical method, the system method, the formal-legal method, the historical-legal method, and the structural method. As a result of this work, the current state of legal regulation of anti-ronavirus medical innovations was analysed, in particular the international legal framework, as well as national legislation in this area; contradictions in the observance of the balance of public and private interests under the conditions of a pandemic are revealed and, consequently, some ways of resolving them are suggested.
\end{abstract}

* Doctor of Jurispridence, Professor, Head of Department of State and Legal Disciplines of National University of Ostroh Academy. ORCID ID: https://orcid.org/oooo-00o2-00o6-8676. Email: iruna. drobush@ukr.net

* Ph. D. in Law, Associate Professor; Associate Professor of Administrative and Financial Law, National University "Odesa Law Academy" ORCID ID: https://orcid.org/oooo-0oo1-7130-6347. Email: Kornutao2@gmail.com

*** Ph.D. in Law, Senior Lecturer, Department of Civil Law, National University of Ostroh Academy. ORCID ID: https://orcid.org/oooo-0oo2-7135-2594. Email: Olha.shmyndruk@oa.edu.ua.

**** Senior Lecturer, Department of State and Legal Disciplines, Institute of Law named after I. Malinovskyi, National University of Ostroh Academy, lawyer. ORCID ID: https://orcid.org/oooo-0002-6364-7114. Email: O.kurganska@gmail.com

***** Ph. D. candidate of Department of State and Legal Disciplines, Institute of Law named after I. Malinovskyi, National University of Ostroh Academy, lawyer. ORCID ID: https://orcid.org/ooooooo1-9010-7474. Email: Polischuk.tatyana@ukr.net

Recibido el 14/12/2020 Aceptado el 19/02/2021 
Keywords: medical innovation; intellectual property; international health crisis; COVID-19; public administration.

\section{Intereses públicos y privados en el ámbito de la administración de la vacunación en una pandemia}

\section{Resumen}

El COVID-19 ha planteado desafíos a la comunidad mundial en general y a la jurisprudencia en particular. En el contexto actual, es de suma importancia encontrar las mejores soluciones posibles en el campo de la regulación legal que ayuden a minimizar los efectos nocivos de la crisis multisectorial global, salvar vidas y restaurar el bienestar de la sociedad. El trabajo tiene como objetivo esclarecer los problemas teóricos en el estatus legal de las innovaciones médicas en el contexto de la pandemia de COVID-19. El tema de la investigación son las innovaciones anticoronavirus en el campo médico. Los métodos de investigación empleados fueron el método dialéctico, el método del sistema, el método formal-legal, el método histórico-legal y el método estructural. Como resultado de este trabajo, se analizó el estado actual de la regulación legal de las innovaciones médicas anticoronavirus, en particular se caracterizó el marco legal internacional, así como la legislación nacional en esta materia; se revelan las contradicciones en el aspecto de la observancia del equilibrio de los intereses públicos y privados en las condiciones de una pandemia y, en consecuencia, se sugieren algunas las formas de resolverlos.

Palabras clave: innovación medicas; propiedad intelectual; crisis sanitaria internacional; COVID-19; administración pública.

\section{Introduction}

The right to health is one of the fundamental human rights. However, during the pandemic, the problem of access to medicines for all social groups becomes extremely relevant. In particular, as of now, vaccination has already begun, mainly in the richest countries in the world. While citizens of poor countries do not currently have access to the vaccine.

On the other hand, there is the problem of the cost of medicines. In particular, the world's leading pharmaceutical companies seek to make money on their innovative products, so their products are often too expensive. 
Iryna Drobush, Liudmila Kornuta, Olha Shmyndruk, Olena Kurhanska y Tetiana Polishchuk
478 Public and Private Interests in the Sphere of Administration of Vaccination in a Pandemic

The high cost of medicines, however, is quite justified - the investment of pharmacological companies in the development and testing of the drug forces the manufacturers of original products to set such a price. The production of cheaper analogs is impossible until the expiration of the patent for the original drug.

Since the outbreak of the COVID-19 pandemic, this problem has become increasingly important, as the speed of overcoming the disease depends on the availability of drugs. Obviously, restricting the rights of patent owners without fair compensation in favor of the public interest is not the best solution. Therefore, there is a need to develop and implement mechanisms that will end restrictions on everyone's right to health care and offset the negative effects of such restrictions on the intellectual property rights of patent holders of medicinal products.

However, such mechanisms should be developed and implemented as soon as possible. After all, every day without a vaccine costs thousands of lives around the world. Accordingly, all governmental and nongovernmental actors involved in the vaccination process should join forces to provide the vaccine to every inhabitant of the planet who wishes to use it.

\section{Results and discussion}

\subsection{Review of International and National Legislation Concerning Legal Regulation of Innovations in the Medical} Field

The Universal Declaration of Human Rights (United Nations, 1948) in Article 25 emphasizes the importance of the connection between an adequate standard of living, medical and social security for the health and normal development of the individual and individual's family. In part 2 of Art. 29, there is a caveat, which postulates that in the exercise of their rights and freedoms, everyone can experience only such restrictions as are necessary to respect the rights and freedoms of others, public morals, the welfare of a democratic society.

Subsequently, the International Covenant on Economic, Social, and Cultural Rights (United Nations, 1966) in Art. Article 12 enshrines the right of everyone to the highest attainable standard of physical and mental health, and, to exercise this right, States Parties have established the obligation to create all necessary conditions for the provision of medical care and in the case of illness.

In 1994, the Declaration on Patient Rights Policy in Europe was adopted, which establishes the right of everyone to receive health care commensurate with his or her health, including preventive and curative care. Moreover, the provision of medical services must correspond to the financial, human, 
and material resources of a particular society and ensure the constant availability of the necessary medical care for all equally, without any discrimination (World Health Organization, 1994).

The main normative legal act of the Ukrainian people (Constitution, 1996) in Article 3 enshrines the duty of the state to take care of the main social value - the person, its health, honor, and dignity; prioritizes the approval of its rights. In Art. 27 of the Constitution, the legislator explicitly prohibits the deprivation of human life, establishes the obligation of the state to protect it. Article 49 of the Constitution of Ukraine affirms the right of everyone to health care, medical assistance, and insurance. These constitutional provisions are detailed in the Fundamentals of the Legislation of Ukraine on Health Care.

Thus, the right to life and health as inalienable natural rights of everyone is reflected in international legal treaties and national regulations. Ukraine is moving towards the harmonization of its legislation with the legal framework and the recommended EU standards in civil protection (Pavlova et al., 2020).

On the other hand, international and national regulations protect intellectual property, including innovations in the medical field. In particular, the Protocol to the Convention for the Protection of Human Rights and Fundamental Freedoms of March 20, 1952, enshrines the right of individuals and legal entities to peacefully possess their property, and this provision protects also intellectual property. However, intellectual property rights began to be regulated long before that. As Ponkin (2013) indicated in his work "History of the development of intellectual property law. The first regulations concerning copyright issues", the need to consolidate intellectual property rights has long been discussed by scientists and lawyers as a way to protect the results of intellectual activity. Even in the VI century BC, in ancient Greece, there was a rule according to which a chef who first prepared a new dish had an exclusive monopoly on cooking it for a certain period.

The oldest registered codified normative act, which contained the basic provisions on patent law, is the Venetian Patent Statute, dated 1474. This act is unique because it established the first patent system in Europe (Samyuta, 2020). However, already in 1812, the first patent law on the territory of the Russian Empire was signed - the Manifesto "On the privileges of various inventions and discoveries in crafts and arts." It established the procedure for obtaining, at that time, privileges for inventions, terms of their validity, and exclusive rights of the owner (Presidential Library, 2020).

The next stage in the development of patent law was determined by the signing of numerous Conventions, Declarations, and Treaties in this area at the international level. Extremely important provisions concerning the 
protection of patents, including the provisions on compulsory licensing, were enshrined in the Paris Convention for the Protection of Industrial Property of March 20 (World Intellectual Property Organization, 1883).

Subsequently, for the development of the patent system on June 19, 1970, the Patent Cooperation Agreement was adopted. The agreement was designed to harmonize many of the then existing patent systems by establishing a set of rules for filing and processing patent applications.

The subsequent adoption of international regulations, which detailed and updated the provisions of previous treaties, was also extremely important. For example, the Patent Law Treaty of June 1, 2000, established the basic requirements for patent applications, the grounds for revocation of a patent. Chapter Five of Part Two of the Agreement on Trade-Related Aspects of Intellectual Property Rights (TRIPS Agreement) (World Trade Organization, 1994) addressed general patenting issues.

To harmonize Ukrainian legislation and bring it in line with international standards, the Constitution of Ukraine enshrines the right of everyone to engage in scientific and technical creativity, approves the protection of intellectual property. The general provisions governing the fundamental issues of protection and enforcement of intellectual property rights were established in the Civil Code of Ukraine (2003). In particular, Chapter 39 defines the concept of subjects of intellectual property rights to an invention or utility model, outlines the basic intellectual property rights to an invention or utility model, and sets the validity of such rights.

Issues of the legal protection of inventions and utility models, the procedure for obtaining, invalidation, termination of a patent and other important issue related to this area were regulated by the Law of Ukraine "On protection of rights to inventions and utility models" (1993). It is also impossible not to note the presence of a large number of bylaws that in one way or another relate to this area of legal regulation. For example, the Order of the Ministry of Education and Science of Ukraine "On Approval of the Regulations on the State Register of Patents of Ukraine for Inventions" of April 12, 2001 No 291, establishes the main provisions concerning the maintenance of such a Register, the procedure for granting a patent for an invention.

With regard to the wider context of the development of world processes, it is thanks to globalization, as a deliberate policy of the developed countries of the world, aimed at the gradual integration of economic, political, sociocultural and other systems, that any person can satisfy his needs in any sphere (Shyshka and Tkalych, 2020).

Thus, there is no doubt about the importance of protecting both the right to health care and intellectual property rights, in particular patents for inventions in the medical field. This is evidenced by the history of adoption 
and the number of extremely important international regulations. However, despite such a variety of legal documents, there has been a debate for many years about balancing the public interest of the public with the right to health care and the private interests of pharmaceutical companies, which appeal to the importance of intellectual property rights and protection of patents for medicines. Outbreaks of new diseases, such as COVID-19, keep the controversy going and force states and the international community to find solutions. New innovative products are created for the implementation of inventions, and therefore it is important to understand how innovations in the medical field are regulated in the legislation, and what problems arise due to the shortcomings of the existing legal regulation.

\subsection{Legal Regulation of Innovations in the Medical Field and Related Problems}

Legal regulation of innovation in the medical field has long been under the close supervision of scholars and lawyers, which is not surprising because the legislation in this area is actively updated in accordance with international standards. However, sometimes, insufficient legal regulation of certain issues leads to significant economic and legal problems.

The Law of Ukraine "On Innovation" (2002) in Part 1 of Art. 1 defines the concept of innovation as products or services, as well as organizational and technical solutions of production, administrative, commercial, or other nature, which significantly improve the structure and quality of production and (or) social sphere.

From the legislative definition of the concept of innovation the following features can be distinguished:

1. it is a thing, information, or process.

2. its mandatory attribute is novelty - such a quantitative and qualitative characteristic that gives reasonable grounds to consider a thing, information or process different from the level of development that preceded them.

3. a prerequisite is the improvement of technological, scientific, etc. level of development due to the emergence of innovation.

4. focus on improving the production and/or social sphere.

According to Art. 4 of this Law, the objects of innovative (aimed at the use and commercialization of research results and developments and which determines the release of new competitive goods and services) activities are: 
1. innovative programs and projects.

2. new knowledge and intellectual products.

3. production equipment and processes.

4. production and business infrastructure.

5. organizational and technical solutions of production, administrative, commercial or other nature, which significantly improve the structure and quality of production and (or) social sphere.

6. raw materials, means of their extraction and processing, and;

7. marketable products; mechanisms for the formation of the consumer market and sales of marketable products.

An innovative product is the realization (implementation) of an object of intellectual property, in particular, an invention, utility model, or industrial design. Thus, to develop a certain innovative product in the medical field, it is necessary to acquire intellectual rights to the invention, which, following Art. 462 of the Civil Code of Ukraine, certified by a patent.

According to the general rule provided for in Part 3 of Art. 465 of the Civil Code of Ukraine, the term of validity of exclusive intellectual property rights to the invention expires twenty years from the date of filing the application for the invention. Original medicines (innovative medicines) are also subject to patenting, which, unlike generic drugs (analogues of original drugs) undergo many pre-clinical and clinical trials before entering the market. It is clear that the synthesis of a new formula, the manufacture of drugs, the above tests are expensive for the manufacturer, and therefore, after such a procedure, the manufacturer has the right to certify its exclusive property right to this invention by patenting it.

Given all the effort and material resources that a patent owner has to obtaining a patent, after entering the market, the cost of such an original drug should be quite significant. That is why there are much cheaper generic drugs, which, however, cannot be produced until the expiration of the patent on the original drugs. Such a legal approach, taking into account the above reasons, is quite justified, objective, and fair. However, the imperfection of domestic patent law has caused the abuse of patenting by certain manufacturers.

We are talking about the so-called "evergreen patents" - a statement that describes the process of obtaining several patents for different forms of active substance and its use of the same drug for a long time. Thus, the release of alternative generic drugs on the Ukrainian market is suspended, and the price of the original drug does not change (Ilyk, 2018). If we turn to the statistics of the World Intellectual Property Organization (1883), it 
becomes clear that the real number of scientific discoveries in Ukraine does not correspond to the number of patents issued in the field of medicine.

Abroad, the main driving force in the fight against "evergreen patents" is to give certain entities the right to challenge manufacturers' patents. In the United States, for example, a special law has been passed that provides a "reward" for a generic company that is the first to challenge such a patent - the ability to sell a generic drug exclusively by that company for a short period of time (Orlova, 2019). This problem has always provoked heated discussions in the domestic legislation, and the ways to solve it have been constantly worked out by many researchers, but until the outbreak of the coronavirus pandemic it was not solved, which negatively affects the speed of overcoming the disease.

However, despite such steps by the US legislature, it should be noted that patent law in the US is developing in a positive direction for patent owners. In particular, amendments were made to the legislation, which provided for the possibility of extending the validity of a patent for medicinal products. Such changes are because the patent owner usually loses a significant part of the term of the patent in order to obtain permission from the regulatory body for commercial marketing and use (Androschuk and Rabotyagova, 2018).

Indian legislation, on the other hand, has long changed in line with the priority of ensuring the public interest. In 1970 an act was issued according to which the inventors of innovative medicines had the right to obtain only a patent for the process of production of such a means. This allowed several companies to produce the same drug at the same time, changing the production process. This has led to lower drug prices and increased access to them (Gupta, 2011).

However, under pressure from the world community, changes were made in 2005 that still gave inventors the right to obtain a patent for the drug itself, and not just for the manufacturing process (Buletsa, 2020).

Thus, we can talk about the different priorities of states in solving the problem of balancing private and public interests in this area. Unlike the United States, where patent law is evolving to protect the intellectual property rights to medical inventions. India, despite global pressures, seeks primarily to ensure that everyone's right to health care is respected and to create a competitive market. The numerous changes in Ukrainian legislation, which are designed to introduce mechanisms for balancing private and public interests in this area, which will be discussed below, also bring Ukraine closer to declaring the priority of public interests. However, the imperfection of the legislation eliminates the possibility of creating an optimal balance.

Problems of Legal Regulation of Innovations in the Medical 
Iryna Drobush, Liudmila Kornuta, Olha Shmyndruk, Olena Kurhanska y Tetiana Polishchuk Public and Private Interests in the Sphere of Administration of Vaccination in a Pandemic

\section{Sphere and Ways to Overcome Them in a COVID-19 Pandemic}

The beginning of 2020 was such a shocking year for many countries of the planet. In early 2020, an outbreak of acute respiratory illness caused by the new SARS CoV-2 coronavirus was reported in Wuhan, Hubei Province, China. The new disease is called COVID-19. On March 11, 2020, the WHO declared the situation with the spread of the pandemic infection.

No matter how much the epidemiological situation caused by the new coronavirus infection, has a negative impact on the world economy, the social sphere, and the collapse of large cultural projects, clever doctors, engineers and scientists are developing inventions that give hope for a global fight against the crisis. Therefore, of special scientific and legal interest are innovations that have become extremely relevant against the background of opposition to the expansion of the disease. To combat the coronavirus, human civilization must mobilize all available resources and develop a common strategy of action, which should be based on a new ethics of relations in the plane of «man-man» and «man-state» (Tkalych, 2020).

Nevertheless, this raises the question: how should medical innovations related to the spread of the new coronavirus be regulated in the legal field? This work tries to find a solution to this problem.

Intellectual property and health care are two interrelated areas when it comes to the coronavirus pandemic.

The fact is that the right holders of medicines used in the fight against COVID-19 may refer to the new use (scope) of their drugs or indicate the exclusivity of the properties of the active substance as a basis for penalties for probation in such categories of cases, indicate unfair commercial use of their intellectual property under the Trade-Related Aspects of Intellectual Property Rights (TRIPS) Agreement as the basis of their claims. In this case, from a moral and ethical point of view, how to assess the restriction of public access to medicines during a pandemic and how will pharmaceutical companies behave after its cessation, when social pressures begin to weaken?

Fortunately, there are arguments in the legal field that give hope that possible disputes will be resolved without harming health care or drug manufacturers.

First, Art. 39.3 of the TRIPS Agreement stipulates that the parties to the agreement, "requiring, as a condition for obtaining marketing authorization for pharmaceuticals or agrochemicals using new chemicals, the provision of undisclosed test data or other data that requires considerable effort. Besides, members shall protect such data from disclosure, except when necessary to protect the public or if no measures are taken to protect such 
data from unfair commercial use." It should be noted here that if patent holders appeal for the protection of trade secrets, are the new chemicals listed in the drugs whose use is disputed? Did the data of the original trials of these drugs remain undisclosed? The last sentence of the mentioned article allows us to use it directly in denying the claims of patent owners because if no measures have been taken to protect trade secrets or public access to information is justified by the urgent need to protect life and health, the obligation to ensure the observance of intellectual property rights does not apply to the signatory state of the TRIPS Agreement, as these are exceptional cases specified in Art. 39.3 of the Agreements.

Secondly, Art. 27.2 of the Agreement TRIPS authorizes WTO members not to allow the patenting of inventions whose commercial use is detrimental to public order or public morals, including the life and health of the population, provided that such prohibition is not limited to restrictions which contained in national law, and paragraph "a" of Art. 27.3 of the Agreement TRIPS provides an opportunity for signatory countries to prohibit the patenting of diagnostic, therapeutic, and surgical treatments for humans or animals. Similar principles are contained in Art. 53 of the European Patent Convention. It is very likely that the German government was guided by these rules, limiting the patenting of some objects under the influence of the pandemic.

As an example of such a restriction, we can cite changes to the German Law governing patent relations. Such changes were proposed in connection with the announcement of the COVID-19 pandemic and provided for the possibility for the state to impose restrictions on the validity of patents for medicines if the state recognizes the existence of the so-called "epidemiological situation of national importance." However, the proprietor of a patent which has been restricted in this way is entitled to receive fair compensation, the amount of which may be challenged in court (Musmann, 2020).

It can be assumed that in the near future the number of cases of compulsory licensing will increase significantly. For example, Canada has already taken advantage of the flexibility of such a legal algorithm. Compulsory licensing is permitted by the relevant Canadian Bill, however, the Act has recently been amended to expedite the issuance of such licenses. Such innovations, as specified in the bill, will work only for the period of the current crisis in the health care system. Such steps indicate the readiness of states to use this method in the fight against a pandemic (Silverman, 2020).

In this regard, a bill was introduced, which should provide such an opportunity. The pharmaceutical community has long been discussing the draft law No 2089 "On Amendments to Certain Legislative Acts of Ukraine to Increase the Availability of Medicines for Citizens" (2020), which was sent for revision by the decision of the relevant Verkhovna Rada 
Committee. In particular, among its shortcomings, the problem of the lack of a quality control mechanism for new drugs is rightly emphasized (Pharmacy Professional Association of Ukraine, 2019).

\section{Conclusions}

The main problem, in the context of the subject of the study, is the conflict of private interests of large pharmacological companies - patent holders and the public interest of society in the context of the right to health care. On this background, there are conflicts between such companies and small manufacturers who seek to compete in the market of coronavirus drugs with maximum speed and minimum production costs. It is clear that to solve these problems it is not enough to limit the rights of pharmacological companies-patent holders. Therefore, to maintain the optimal balance of interests, certain legal mechanisms, the implementation of which in Ukraine, in the absence of proper legal regulation, can cause serious problems were analyzed.

In particular, the following conclusions were drawn as a result of the study.

1. Abuse of the right of patent owners to certify their property rights to inventions by constantly obtaining new patents for different properties of the same drug delays cheaper analogues to entry into the market. The solution to this problem, which has been vital for our society for a long time, can only be reforming the legislation, which will eliminate the possibility of such abuse. By analogy with many foreign countries (including the United States), it is necessary to allow certain entities to challenge patents of manufacturers.

2. The use of a compulsory licensing mechanism, according to many researchers, is currently risky. Due to the lack of court precedents and explanations of the relevant state bodies, such conditions as the groundlessness of the patent owner's refusal to grant a license, the terms of such compulsory licenses, and the proportionality of compensation are estimated. It will be a good idea to ask the state or the judiciary to publish official explanations that will provide answers to such questions.

3. The main problem with the introduction of the parallel import mechanism in Ukraine is the possibility of certain negative consequences, in particular, an increase in the flow of counterfeit products. To mitigate such effects, it is necessary to prescribe at the legislative level the entire procedure for parallel imports, up to the admission of such drugs to the market. As one of the solutions to the situation of the distribution of counterfeit products, we can propose the creation of specialized customs posts for such importers. 
4. The mechanism of accelerated filing by manufacturers for registration of generic versions of patented drugs is quite positive but does not seem effective enough in counteracting the coronavirus pandemic, as some patents have only entered into force and will not expire for a significant period of time.

5. The conclusion of controlled access agreements, due to their confidentiality, is accompanied by certain corruption risks. To solve this problem, by analogy with countries such as Sweden and the United Kingdom, it is possible to create appropriate registers of controlled access agreements with open information about drugs for which such agreements have been concluded. Also, there is always a problem of lack of funds in the state and local budgets for the purchase of drugs under such agreements.

6. Besides, one of the possible solutions to the main problem of maintaining the balance of private and public interests may also be the conclusion of exclusive long-term contracts with pharmaceutical companies for the use of their means to combat coronavirus, which will provide appropriate legal support and royalties in the long run. Another possible vector of development is the reform and increase of funding for the field of national pharmacology, which will aim to create high-quality drugs at affordable prices from the manufacturer.

Therefore, to prevent restrictions on the right of everyone to health care we consider it necessary to introduce the above-mentioned mechanisms. However, in order not to affect the intellectual property rights and interests of patent owners, it is important to properly and accurately regulate them in the legal field. This will not only protect the interests of all stakeholders, but also prevent abuse.

\section{Bibliographic References}

ANDROSCHUK, Grygorii; RABOTYAGOVA, Larysa. 2018. "Problems of patenting inventions in the pharmaceutical industry: economic-legal aspect (Part I)" In: Science, technology, innovation. Vol. 4, pp. 58-67. Available online. In http://nti.ukrintei.ua/wp-content/uploads/2020/o 1/\%Do\%90\%Do\%BD\%Do\%B4\%D1\%80\%Do\%BE\%D1\%89\%D1\%83\% Do\%BA-2_3-18.pdf. Consultation date: 07/02/2020.

BULETSA, Sibilla. 2020. Features of the contract of controlled access in the conditions of COVID-19. Available online. In: http://dspace.onua.edu. ua/handle/11300/12616. Consultation date: 28/04/2020.

CIVIL CODE OF UKRAINE. 2003. Available online. In: https://zakon.rada. gov.ua/laws/show/435-15. Consultation date: 07/02/2020. 
CONSTITUTION OF UKRAINE. 1996. Available online. In https://zakon.rada. gov.ua/laws/show/254\%Do\%BA/96-\%Do\%B2\%D1\%80. Consultation date: $07 / 02 / 2020$.

GUPTA, S.K; SINGHVI, I.J; SHIRSAT, M; KARWANI, G; AGARWAL, A. 2011. "Drug Patent System in India and its Application" In: Asian Journal of Pharmaceutical and Clinical Research. Vol. 1, No. 1, pp. 13-24. Available online. In https://www.researchgate.net/publication/313860747_ Drug_Patent_System_in_India_and_its_Application. Consultation date: 07/02/2020.

ILYK, Roman. 2018. Patent reform: how to make medicines more affordable? Ukrainian Pravda. Available online. In: https://life.pravda.com.ua/ columns/2018/02/6/228825/. Consultation date: 07/02/2020.

LAW OF UKRAINE. 1970. Patent Cooperation Agreement: Law. Available online. In https://zakon.rada.gov.ua/laws/show/895_o01\#Text. Consultation date: 07/02/2020.

LAW OF UKRAINE. 1993. On protection of rights to inventions and utility models: Law 3687-XII. Available online. In https://zakon.rada.gov.ua/ laws/show/3687-12\#Text. Consultation date: 07/02/2020.

LAW OF UKRAINE. 200o. Patent law Treaty. Available online. In https:// zakon.rada.gov.ua/laws/show/895_002\#Text. Consultation date: 07/02/2020.

LAW OF UKRAINE. 2002. On Innovation: Law 40-IV. Available online. In https://zakon.rada.gov.ua/laws/show/40-15\#Text. Consultation date: 07/02/2020.

LAW OF UKRAINE. 2020. On Amendments to Certain Legislative Acts of Ukraine to Increase the Availability of Medicines for Citizens: Draft law 2089. Available online. In http://search.ligazakon.ua/1_doc2.nsf/link1/ JIo0429A.html. Consultation date: 07/02/2020.

MINISTRY OF EDUCATION AND SCIENCE OF UKRAINE. 2001. On approval of the Regulations on the State Register of Patents of Ukraine for Inventions: Order 291. Available online. In https://zakon.rada.gov. ua/laws/show/z0379-01\#Text. Consultation date: 02/04/2020.

MUSMANN, Thomas. 2020. German Government Plans Possibilities to Limit Patents In View of Corona Pandemic. In: Kluwer Patent Blog. Available online. In http://patentblog.kluweriplaw.com/2020/o3/24/germangovernment-plans-possibilities-to-limit-patents-in-view-of-coronapandemic/. Consultation date: 02/04/2020. 
ORLOVA, Alyona. 2019. Patent Strategies in Pharmaceuticals: Patent Greening. In: Journal of the Intellectual Property Rights Court. No 26. pp 8389. Available online. In: http://ipcmagazine.ru/patent-law/patentstrategies-in-pharmaceuticals-patent-gardening. Consultation date: 07/02/2020.

PAVLOVA, Yuliia; POLUNINA, Olha; TKALYCH, Maxym; MANKOVSKYI, Volodymyr; ZUBAIR, Akhmad. 2020. "International-legal standards of cooperation of ukraine in the field of environmental (climate) problems" In: Amazonia Investiga. Vol. 9, No. 25 pp. 295-301.

PHARMACY PROFESSIONAL ASSOCIATION OF UKRAINE. 2019. Parallel import of medicines. Is it good or bad for the patient in Ukraine? Available online. In: https://bit.ly/2CN4gzV. Consultation date: 07/02/2020.

PONKIN, Ivan. 2013. "History of development of intellectual property law. The first normative acts dealing with copyright issues" In: Bulletin of the Friendship between nations University of Russia (series: legal sciences). Vol. 3, pp. 124-129. Available online. In: https://cyberleninka.ru/ article/n/istoriya-razvitiya-prava-intellektualnoy-sobstvennosti-pervyenormativnye-pravovye-akty-kasavshiesya-voprosov-avtorskogo-prava/ viewer. Consultation date: 07/02/2020.

PRESIDENTIAL LIBRARY. 2020. A manifesto "on privileges for various inventions and discoveries in crafts and arts" was signed - the first patent law in Russia. Available online. In https://www.prlib.ru/history/619346\#: :text=17\%20(29)\%20 \%Do\%B8\%D1\%8E\%Do\%BD\%D1\%8F\%201812\%20\%Do\%B3,\%Do\%B F\%D1\%80\%Do\%B8\%Do\%BD\%Do\%B8\%Do\%BC\%Do\%Bo\%D1\%82\% D1\%8C\%D1\%81\%D1\%8F\%20\%Do\%B2\%20\%Do\%B1\%Do\%BE\%Do\% BB\%D1\%8C\%D1\%88\%Do\%B8\%Do\%BD\%D1\%81\%D1\%82\%Do\%B2\% Do\%B5\%20\%Do\%B5\%Do\%B2\%D1\%80\%Do\%BE\%Do\%BF\%Do\%B5 \%Do\%B9\%D1\%81\%Do\%BA\%Do\%B8\%D1\%85\%20\%Do\%B3\%Do\%B E\%D1\%81\%D1\%83\%Do\%B4\%Do\%Bo\%D1\%80\%D1\%81\%D1\%82\%Do \%B2. Consultation date: 02/04/2020.

SAMYUTA, Pavel. 2020. "A Brief History of the Patent: Past and Present of Patent Law" In: LiveJournal. Available online. In https://pavel-samuta. livejournal.com/20898.html. Consultation date: 02/04/2020.

SHYSHKA, Roman; TKALYCH, Maxym. 2020. "The World in 2020: What Are the Threats To Humanity?” In: Amazonia Investiga. Vol. 9, No. 26, pp. 3-5.

SILVERMAN,Ed. 2020.ACanadian billwould makeit easier to issue compulsory licenses for COVID-19 products. In: Stat. Available online. https://www. 
Iryna Drobush, Liudmila Kornuta, Olha Shmyndruk, Olena Kurhanska y Tetiana Polishchuk

490 Public and Private Interests in the Sphere of Administration of Vaccination in a Pandemic

statnews.com/pharmalot/2020/03/25/canada-compulsory-licensecoronavirus-covid19/. Consultation date: 02/04/2020.

TKALYCH, Maxym; SAFONCHYK, Oksana; TOLMACHEVSKA, Yuliia. 2020. "Private Law and human rights: New realities" In: DIXI. Vol 22, No. 2. pp. 1-12.

UNITED NATIONS. 1948. Universal Declaration of Human Rights. Available online. In https://www.un.org/en/universal-declaration-humanrights/. Consultation date: 07/02/2020.

UNITED NATIONS. 1966. International Covenant on Economic, Social and Cultural Rights. Available online. In https://www.ohchr.org/en/ professionalinterest/pages/cescr.aspx. Consultation date: 07/02/2020.

WORLD HEALTH ORGANIZATION. 1994. Declaration on Patient Rights Policy in Europe. Available online. In https://www.who.int/genomics/ public/eu_declaration1994.pdf?ua=1. Consultation date: 07/02/2020.

WORLD INTELLECTUAL PROPERTY ORGANIZATION. 1883. Paris Convention for the Protection of Industrial Property. Available online. In https://www.wipo.int/treaties/en/ip/paris/. Consultation date: 07/02/2020.

WORLD TRADE ORGANIZATION. 1994. Trade-Related Aspects of Intellectual Property Rights. Available online. In: https://www.wto.org/english/ tratop_e/trips_e/trips_e.htm. Consultation date: 07/02/2020. 

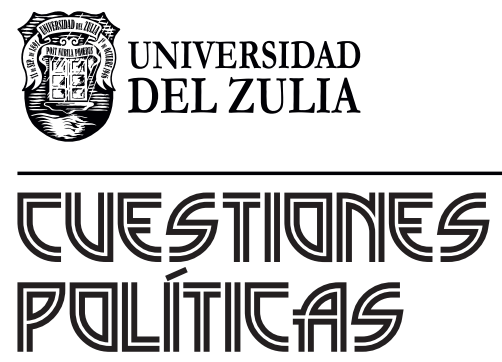

Vol.39 No 68

Esta revista fue editada en formato digital y publicada en enero de 2021, por el Fondo Editorial Serbiluz, Universidad del Zulia. Maracaibo-Venezuela 